\title{
UZLAŞMA/NIN FELSEFESi
}

\author{
The Philosophy of Reconciliation
}

\author{
Prof. Dr. Celal TÜRER*
}

Geliş Tarihi: 10.04.2016 Yayına Kabul Tarihi: 26.05.2016

\section{Öz}

Uzlaşmayı felsefi açıdan anlama çabası, günümüzde uzlaşma yerine niçin çatışmanın ön planda olduğuna ve uzlaşmanın niçin etkin kılınamadığına dair soruları anlamada katkı sağlayacaktır. Bu çerçevede "uzlaşma"nın epistemolojik, ontolojik ve aksiyolojik görünümlerinin incelenmesi bu anlama çabası için önem taşır. Uzlaşmanın epistemolojisi söz konusu olduğunda doğruluğa dair yaklaşımımızın uzlaşmayı sağlamada belirleyici olduğu görülür. Uzlaşmanın ontolojisine gelince, bu konu hem batı hem İslam düşünce tarihinde birlik/çokluk ilişkisine dair farklı yaklaşımlar üzerinden okunabilir. Bu bağlamda varolanların Bir'de toplanması fikri, varlığın ontolojik bir uzlaşı gösterdiğini resmeder. Uzlaşma, ahlaki bir hadiseye işaret ettiği için uzlaşmanın aksiyolojisini anlamak da oldukça önemlidir. Değerler alanı, irade sahibi varlıkların katıldığı ve buluştuğu bir alan olduğu için bu alanda başka değerlere saygı duymak, toplumdaki bireylerin buna yönelik çabaları, uzlaşmaya katkı sunacaktır. Bu çerçevede uzlaşma, herkesin kendi değerleri ile ortak iyide uzlaşması, kendisiyle öteki arasında barış ve güvenlik ortamı sağlama yönündeki çabası olarak anlaşılmalıdır.

Anahtar Kelimeler: Uzlaşma, Çatışma, Doğruluk, Birlik/Çokluk, Değerler.

\footnotetext{
* Celal Türer, Prof. Dr., Ankara Üniversitesi İlahiyat Fakültesi Felsefe Tarihi A. B. D. Öğretim Üyesi, cturer@ankara.edu.tr
}

\begin{abstract}
The attempt of the finding out the reconciliation philosophically will contribute to understand why the conflict is at the forefront instead of reconciliation and why the reconciliation could not be dynamised in our time. Within this framework, it is important to analyse the epistemological, ontological and axiological appearance of the "reconciliation" for providing this understanding. Considering the epistemology of reconciliation it is seen that our approach to the truth is decisive in achieving reconciliation. As regards to the ontology of reconciliation, this issue may be followed by the different approaches to the relationship between unity and diversity both in Western and Islamic philosophy. In this context, the idea of the gathering of beings in One represents that the being shows an ontological reconciliation. It is also important to comprehend the axiology of reconciliation due to the fact that reconciliation points out an ethical phenomenon. Since the realm of values is the ground where the human beings with free will come together, in this realm having respect for the other values and endeavors of the individuals towards this will contribute to the reconciliation. Within this scope, the reconciliation should be understood as the reconciliation of everybody with their own values on the common good and the effort of them to provide a peaceful and confident environment.
\end{abstract}

Keywords: Reconciliation, Conflict, Truth, Unity/ Diversity, Values. 


\section{GİRİ̧}

Uzlaşma, çağın dünyasında çok fazla konuşulduğu halde nasıl gerçekleştirileceği konusunda uzlaşmanın olmadığ karşımıza çıkmaktadır. İnsanoğlu sadece kendisini değil tüm gezegeni tehdit eden sorunlarla karşılaştıkça "uzlaşacağı" öngörüsünün aksine uzlaş/a/mamakta; böylelikle geleceğimizi tehdit eden bir yola girmektedir. Hatta pek çok hayati mevzuda çoğu zaman uzlaşmamayı normal kabul etmeye yönelmektedir. Bu çerçevede çağdaş insanın uzlaşma yerine çatışmayı hem kendi hayatının özgül katmanlarında hem de toplumsal hayatın her katmanında yaşadığı, bir nevi benimsediği söylenebilir. Öyle ki çatışma bugün hem bireysel hem de toplumsal yaşamı biçimlendirmekte, organize etmekte; tercihlerimizi, hedeflerimizi veya isteklerimizi etkilemekte hatta yönlendirmektedir. Çatışmanın günümüz yaşam tarzını karakterize ettiğini söylemek artık abartı değildir. Hatta "çatışmadan kaçınmalıyız", "çatışmanın faydası olmaz", "çatışma, çatışmaları derinleştirir” türünden dolaşıma sokulmuş onca özlü, bilgiççe ve bazen de çaresizce söylenmiş sözler de esasen çatışmanın kıyısından ses veren, çatışmanın farklı yüzünü ve yelpazesini gösteren bir dili temsil etmektedir. Peki, "uzlaşma" niçin hala aklıselimle ölçümlenen, faydalarımızla hesaplanan hayatlarımızda, utanç içerisinde bastırmak zorunda olduğumuz bir görüngüye dönüşüyor? Uzlaşmanın makul görünen her türlüsüne niçin gönül rahatllğıyla "evet" diyebilmenin konforuna değil de çatışmanın çaresizliğine tutsak oluyoruz? Hayatımızdaki derin çatışmalara karşı söz üretirken, en azından onurumuzu kurtarmak adına pek çok konuda niçin "uzlaşma" cesaretini gösteremiyoruz? Tüm bu sorular uzlaşmayı farklı bir ruh ikliminde -modern insanın unuttuğu bir derinleşme içerisinde- yani felsefi açıdan anlamayı gerekli kılmaktadır.

Uzlaşmanın ne olduğuna dair arayışlarımız, ilk planda "uzlaşma" kelimesinin etimolojik yol göstericiliğine müracaat etmemizi zorunlu kılmaktadır. Bu husus, tüm diğer kavramlar gibi bizzat "uzlaşma" kelimesinin her daim konuşabilme ve anlamlı olabilme özelliğini koruyabilmesinden kaynaklanır. Peki, "uzlaşma” kelimesi bize nasıl ve nereden konuşabilmektedir. Bu hususu anlayabilmek için kelimelerin ya da kavramların neyi ifade ettiğine, bize nasıl seslendiğine bir göz atmak gerekir. Gerçekten kelimeler, mefhumun tarihsel serüveninin kesitlerini veya yapısal durumunu sergilediği kadar, insan bilincine kendisini 
dayatmakta olan tarihsel gerçekliği seslendirir. İster Arapça "تصالح"kelimesini, isterse Latince "reconciliationis" kelimesinden gelen ve bat1 dillerine "reconciliation" olarak geçen kelimeyi ele alalım; bu kelimelerin ardında, insan bilincine kendisini dayatmakta olan bir gerçekliğin mevcut olduğunu fark ederiz. Nitekim uzlaşma kelimesi farklı dillerde bir şeyin yapılma tarzına işaret edip "anlaşma" gibi anlamları içerirken, yapılan şeyi vurgulayan uzlaşı ise "mutabakata varmak" gibi manaları taşımaktadır. Bu kavramın Yunanca'daki karşılığı olan $\Sigma v \mu \varphi \imath \lambda i ́ \omega \sigma \eta$ fiil olarak "iyi ilişkileri tesis etmek" anlamını ifade eder. Arapça'dan dilimize geçen "sulh" kelimesi ise süreçten çok sonuca bir göndermede bulunarak eylemin yapısını yansıtır. Yine söz konusu kelime Roma Katolik Kilisesi'nde "günahın itirafını, onun pişmanlığını" muhtemelen insanın hem kendisiyle uyuşmasını hem de Tanrı'yla uyuşmasını temsil etmektedir. Tüm bunlardan uzlaşma kelimesinin çoğunlukla "farklı birey, farklı grup, farklı fikir, inanç ve durumları uyuşturma süreci" anlamına geldiğini çıkartabiliriz. Çünkü uzlaşma aralarında farklılık bulunan hususlarda oluşan hadiseye işaret eder. Yoksa insanların sadece fikir ve inançlarda değil; tat, arzular, dilek ve amaçlar gibi pek çok şeyde anlaşmaması doğaldır. Sorun esasen hayatın akışını engelleyen farklılıkların nasıl uzlaştırılacağı hususundadır.

Düşünce tarihinde inanç ve değerlendirmelerin uzlaşısını ya da birliğini ifade eden "uzlaşma"nın çoğu kez varoluşun derunundaki bir husus ile gerçekleşeceği ya da garanti altına alınacağı ifade edilmiştir. Sözgelimi Ortaçağ'da Aquinas ancak Tanrínın garanti edeceği bir zeminde uzlaşmanın oluşacağını; on sekizinci yüzyılda Kant onun Aklın doğasında mevcut olduğunu; on dokuzuncu yüzyılda Hegel uzlaşmanın tarihsel yürüyüş içerisinde Cemiyet'te gerçekleşeceğini; yirminci yüzyılda Habermas, İletişim'in doğasında mevcut olacağını ifade etmiştir. Tüm bu girişimler umut/arzu edilen uzlaşmanın varoluşun doğasında yatan ilkelerle sağlanacağı yönündedir. Görüldüğü gibi uzlaşım kelimesinin farklı dillerdeki ifadesi ve farklı yaklaşımları kendisini sürekli bilince dayatan "uzlaşma, anlaşma" gerçekliğine ve ona dair yaklaşım "tarzına veya perspektifine" işaret eder. Ancak uzlaşmanın insanlığın varacağı nihai bir nokta gibi algılanması da meselenin derinliğini unutmak olur. Zira varoluş devam ettiği müddetçe çatışmanın mevcut olacağı lakin bu durumun "meşru farklılık", "ölçülü uyumsuzluk", "farklılıktaki uysallık", "diğerlerinin otonomisine sayg”" 
çerçevesinde anlaşılması gerekecektir. Nitekim bu husus uzlaşmayı anlamaya çalışırken "çatışma" kavramına da müracaat etmeyi gerektirecektir. Açıktır ki anlaşmazlık ya da çatışma, Türkçe'de "çatışmak işi”, "aynı anda ortaya çıkan birbirine karşıt ya da eşit derecede çekici dilek ve isteklerin bireyde yarattığı ruhsal durum", "birbirleriyle uyuşmayan dilek, istek ya da ereklerin yarışmasından ortaya çıkan üzücü ya da kıvanç vermekten uzak bilinç durumu", basitçe "görüş ve kanıların aykırılığından doğan karşıtlık" ya da "silahlı büyük kavga, arbede" anlamlarına gelmektedir. Bu durum ilk bakışta "uzlaşma" ve "çatışma"nın farklı durumları, dahası birbirine zıt durumları temsil ettiğini göstermektedir. Oysa derinlemesine bakıldığında, varoluşun ontik yapısının "ilişki" olduğunu fark ettiğimizde esasen uzlaşma ya da çatışmanın aynı şeyin farklı görünümleri olduğunu anlarız. Bu yüzden makalede, "uzlaşma"nın epistemolojik, ontolojik ve aksiyolojik görünümlerini inceleyerek onun hayatımızdaki yerini ortaya koymayı deneyeceğiz.

\section{Uzlaşmanın Epistemolojisi}

Gerçekten mükemmel olmayan bir dünyada yaşadığımız ve elimizdeki kaynakların, entelektüel kaynaklarımız da dâhil olmak üzere s1nırlı olduğu kabul edilen bir olgudur. Buna ilaveten çatışmanın ya da anlaşmazlıkların yaygın olduğu bir dünyanın tehlikelerinin bizler için ne anlama geldiğinin farkındayız. Bu yüzden gerek küresel gerekse yerel uzlaşmaların çoğaldığı bir dünya için hazırlık yapmamız gerektiğini; bilgi ve araştırmalarımızın, olumsuz yönde ilerleyecek hiççilik/ nihilizm ile uzlaşmanın tek bir doğrultuda oluşacağını iddia eden dogmatiklik arasında bir yerde olacağını görmemiz gerekir. Bu doğrultuda gerçekleşecek teorik ve pratik amaçlar, çatışmaların çözüleceği makuliyet ve sosyal düzen/ahenk fikrine hizmet etmelidir.

Uzlaşmanın varoluşta bir insan tavrı olarak tezahür ettiği aşikârdır. Bu tavır iki tip yaklaşımı gözler önüne serer. Bunlardan ilki, salt uzlaşmacı diğeri ise çoğulcu tavırdır. Salt uzlaşmacı her türlü anlaşmazlık ya da ahenksizlikten kaçınmak için her hususta uzlaşma yapmayı önerir. Oysa çoğulcu, karmaşık ve mükemmel olmayan bir dünyada kaçınılmaz çatışmaların mevcudiyetini kabul eder ve dünyayı anlaşmazlığın azalacağı bir mekâna dönüştürmeye çalışır. İlkinin amacı çatışmadan kaçınma siyaseti iken ikincinin amacı çatışmanın yönetilmesi hususudur. Günümüzde bilgi felsefecilerinin uzlaşmaya odaklanmamız 
gerektiği hususundaki ısrarlarına dikkat edersek, onların sorunu bilgiye dair insani çabalarda gördüklerini fark ederiz. Kant'ın iddia ettiği gibi tüm insani yargılar, nihayetinde "Düşünüyorum ki" şeklinde şahsi yargilardır. P'nin doğruluğuna dair her nerede bir inanç ya da kanaat varsa bu benim P'yi doğru düşündüğüm anlamina gelir. İster bilimde isterse sosyal hayatta "doğru", doğru olduğunu düşündüğümüz şey vasıtasıyla ortaya çıkar. Herhangi bir konuda doğrudan ona ulaşacağ1mız; inançlarımızdan bağımsız, şahsi olmayan bir doğruluk yolu yoktur. Bu noktada "Düşünüyorum"un yerine "Düşünüyoruz ki”" şeklinde bir uzlaşmanın önemli bir adım olacağını unutmamak gerekir.

Uzlaşmanın epistemolojik gerçekliğini hakikat ya da doğruluk arayışında/sorununda görebiliriz. Hayatın tüm alanlarında kullandığımız hakikat ya da doğruluk, basitçe düşüncenin gerçekle uyuşması, yargı ve önermelerin gerçeğe uygun olması anlamına gelse de, yapılan bu tanım doğruluğa dair sorunları ortadan kaldırmaz. Düşünce tarihinde "doğruluğun ne olduğu" sorusuna verilen klasik yanıt, Heidegger'in de belirttiği gibi, üç tez çerçevesinde karakterize edilmiştir: 1) Doğruluk "yerini" bir yargıda bulur; 2) Doğruluğun özü, yarg1 ile yarg1 konusunun mutabakatına bağlıdır; 3) Doğruluk, Aristoteles'in etkisiyle, hem yargının bir özelliği hem de "tekabüliyeti" olarak tanımlanmıştır. ${ }^{1} \mathrm{Bu}$ çerçevede oluşan mevcut tekabüliyetçi doğruluk kuramının realist bir yaklaşımı yansıttığ1 ve ontolojik nitelikteki tartışmalar merkezinde geliştiği ileri sürülebilir. İdealist filozofların benimsediği tutarlılık kuramının ise doğruluğu bir önermeler sistemi içinde anladığı; doğruluğun inançların, düşüncelerin, bilgilerin kendi aralarında birbirleriyle uyuşmalarından başka bir şey olmadığı kabul edilir. On dokuzuncu yüzyılın sonlarına doğru pragmatist filozoflar ise doğruluğun deneyimsel karakterine vurgu yaparak, literatürde "kılgısal kuram", "pragmatik kuram" adlarıyla geçen bir doğruluk kuramı önermişlerdir.

Günümüzde doğruluğun bir uygunluk hali mi, bir tutarlılık konusu mu, yoksa bir uzlaşım sorunu mu olduğu üzerine önemli kuramsal tartışmalar, yön değiştirerek ve yeni boyutlar kazanarak devam etmektedir. Doğruluk kuramlarıyla ilgili yaygın kanaat, onların mutlak, genel geçer ve her durumda bir ölçüt olmadıkları, dolayısıyla, önermelerin doğruluğuna ilişkin söz konusu kuramlara dayalı yapılan

${ }^{1}$ M. Heidegger, Varlık ve Zaman, çev. Kaan. H. Öktem, İstanbul, 2008, s. 226 
değerlendirme sonuçlarının kesin görülmemesi gerektiği yönündedir. ${ }^{2}$ Bu sebepten insan hayatının her alanında değişmez doğrular aramanın, sadece inançlarda olacağı aşikârdır. Zira Mutlak doğru, tecrübemizde olmadığından yoktur. Ancak o, tüm geçici doğrularımızın bir gün birleşeceğini tahayyül ettiğimiz ya da varsaydığımız ideal bir noktayı temsil edebilir. Dolayısıyla bizler hâlihazırda elimizdeki doğrularla yetinmeli veya muhtemelen onlara yanlış demeye hazırlıklı olmalıyı. Sözgelimi Batlamyus astronomisi, Öklid geometrisi, Aristoteles mantığı, Skolastik metafizik yüzyıllar boyu insan hayatına faydalı olmuştur ama insan düşüncesi bu anlayışların sınırlarını aşmıştır. Bizler bugün onlara "göreli doğru" veya deneyimin o andaki sınırları içinde "doğru olan şeyler” diyoruz. Bu çerçeveyi kabul ettiğimizde, Caesar'ın kendisi doğrudur, Tufan'dan önceki canavarlar doğrudur, fakat bunların tümü kendi zamanlarında doğrudur. Eğer onlar mutlak olarak ele alınırlarsa, yanlış olurlar. Zira biliyoruz ki geçmişin kuramları ya da deneyimin o anki sınırları tesadüfî idi ve bugünün düşünürleri o kuram ve sınırları aştığı gibi, biz de sözü edilen mevcut doğruları aşabiliriz. ${ }^{3}$

Kabul edilmelidir ki her ferdin doğrulukla ilgili ölçütü, kendi inanç sistemine ve kişisel deneyim bağlamına aittir. Bu noktada hemen şu akla gelebilir: Acaba, kişisel doğrular bize bir görecelik mi önerir? Öncelikle doğrulukla ilgili analizlerden hareketle, doğrunun tümüyle kişisel ve eğilimlere bağlı bir husus olmadığını, aynı şekilde onun tümüyle nesnel bir hususu da yansıtmadığını hatırlayalım. Bu nokta bireyin kendi sübjektif "doğrularından" başlayarak, kendi tecrübesinin dışında başka herhangi bir şeye müracaat etmeden, doğru fikirlerin nesnelliğini tesis etmeye yöneldiğine işaret eder. Bu anlayışa göre birey belli bir zamanda izafi doğrularından başlayarak ve araştırıcılar topluluğu tarafından dereceli olarak oluşturulan daha nesnel yargılar demetinin aracı aşamalarıyla nihaî olarak nesnel doğrulara ulaşır. Bu husus doğruluğun sabit bir nitelik olarak görülmediğini, doğruluğun nihayetinde topluluk tarafından oluşturulduğunu ifade eder. Bu noktada doğruluk fikirden ibaret olduğu için, bir fikrin doğruluğunun da kendisini doğrulayan süreçten başka bir şeye işaret etmediğini görmemiz gerekir. Bu noktadan hareketle tüm doğruların insan ürünü olduğunu; zaman ve

$\overline{2}$ Zekiye Kutlusoy, "Doğruluk Kuramları” Felsefe Ansiklopedisi, ed. Ahmet Cevizci, Ankara, 2006, C. 4, s. 670.

${ }^{3}$ James, Pragmatism, New York, 1907. s. 222-223. 
mekan içerisindeki doğrulama süreçleriyle oluştuğunu söyleyebiliriz. Nitekim kendinde gerçeklik ile hiç bir zaman karşılaşmayan insanın, gerçekliğin deneyimlenen görünümlerine dikkat kesilerek anlamlı bütünler oluşturabildiğini söyleyebiliriz. ${ }^{4}$ Bu husus, doğru fikirlerin hayati ihtiyaçlarımızdan ortaya çıktığına ve onların giderilmesinin ancak deneyimde tatmin edilmesiyle gerçekleşeceğine işaret eder. Eğer hayatî ihtiyaçlarımızın en önemlileri estetik, etik ve dini sahada ise, doğruların bu alandaki eğilimlerimizi gidermesi ve taleplerimizin bu doğrulara göre uyarlanması gerekir.

Doğruluğun özneler arası bir uyuşma olduğu günümüzde oldukça kabul gören bir anlayışı temsil eder. Yaygın bir öyküye göre; "Bir köylüye çayırının yeşil, ineklerinin kırmızı, atlarının siyah olduğuna neden inandığı sorulursa, o kuşkusuz şu yanıtı verecektir: Gidip bakalım mı! Tartışma daha ileriye taşınıp gördüklerinin doğru olduğuna neden inandiğı sorulursa köylü, bu soruyu ya yanıtlamaya değmez görecek ya da "herkes öyle olduğuna inandığı için" diyecektir. Bu husus, doğruluğun başkalarının öyle düşünmelerine, yani başka öznelere dayandığına gönderme yapar. Buradan hareketle geliştirilen doğruluk kuramı, "bir önerme her konuşmacı tarafından kabul ediliyorsa doğrudur" ana düşüncesine dayanır. Burada doğruluğun nesnelliği, önermenin her konuşmacı tarafından kabul edilmesine bağlanır. Eğer kabul edilen şeyin neye ilişkin olduğu da açıklanırsa görüş tam olur. En yalın versiyonuyla veya sağduyu düzeyindeki anlamıyla uzlaşmacı doğruluk anlayışı etik bir içerim ve diğer teorilerden daha ikna edici bir içerik taşır.

\section{Uzlaşmanın Ontolojisi}

Varolanların ne olduğu ve varolanlardan soyutlanarak çıkartılan varlık sorusu etrafında şekillenen ontoloji, Platon'dan Hegel'e kadar varlığın "ne olduğu sorusunun" yanı sıra "özde ne türden ayrı şeylerin var olduğunu" araştıran bir alanı temsil etmiştir. Bu alan hem ferdi, hem tikel varlıklardan en genel, en üniversal varlığa kadar hepsini içine alan bir araştırmayı ortaya koymuştur. Nitekim Aristoteles, var olanların varlık olmak bakımından incelenmesine İlk Felsefe adını vermiş; bu felsefeyle ilk ilkeleri ya da çürütülemez hakikatleri ortaya koymaya çabalamıştır. Ona göre insan varolanları ya da varlığı kendi

${ }^{4}$ Celal Türer “Pragmatizm'in Doğruluk Evi”, Bilimname, XVII, 2009, s. 269-175 
başına ele alamadığı için, varolanları her daim "âlemde varlık" olarak görmüş, onları kendi gerçekliğinde incelemeye çalışmıştır. Zira varolanların oluşturduğu âlem insan zihninin üretmediği, bunun yanı sıra onun elinin altında bulunan şeylerden ibaret bir âlem değildir. Aksine bu âlem varoluşumuzun kendisine bağlı olduğu ama diğer taraftan şuurumuzun onu aşmaya çabaladığı bir âlemi temsil eder. Bu durum, sonsuzu yaşayamazsak da düşündüklerimizle sonsuza uzanmaya çabaladığımız; muhtemelen varlıkta görüneni ya da zihnimizin görmek istediği idraki yansıtır. Bu idrak dış dünyada nizam ve iç dünyamızda ise uysallık olarak isimlendireceğimiz fitrat olarak anlaşılabilir.

Antik Yunan filozofları, yukarıda anlatılanların ışığında varolanlardan hareketle onların kendisinden çıktığı Bir'e, her şeyin özü ve bütün mümkünlerin kaynağı olan Sonsuz'a doğru hareket etmişlerdir. Nitekim ilk doğa filozofları, çokluğun/kesretin arkasındaki Birlik'i/ Vahdet'i hemen fark etmişler; her şeyin kendisinden çıktı̆̆ "arkhe"yi aramışlardır. Herakleitos, oluşu, yani karşıtların karşılıklı olarak birbirleriyle denge durumunda olduğu "evrimsel" bir süreci görmüş, hatta çatışmanın kendisini uyum olarak nitelemiştir. Parmanides, bizzat var olmanın kendisini keşfederek; "varlık vardır, varlık tektir ve varlık değişmez" diyerek çokluk, çeşitlilik ve değişmenin olmadığını ifade etmiştir. Parmanides'in metafizik birciliği, görünüşle gerçeklik arasında ayırım yapar. Kökleri Hint düşüncesine kadar uzanan söz konusu birciliğe göre, duyu deneyimi, dünyamız, bir yanılsamadan başka bir şey olmayıp, çokluk, değişme ve nedenselliğin gerçek olmadığına işaret eder. Felsefi düşüncede Bir ve Çok'un birleştirilmesi Aristoteles'in cevher/töz fikriyle başlamıştır. Plotinus birlikten çokluğa ve çokluktan birliğe geçişi statik ve cevherci görüşten kurtarmış, varolan her şeyi içeren Birlik'i tanıtmıştır. Ortaçağ felsefesi, birlik ve çokluğu Tanrı fikrinde eriterek bazen statik bazen dinamik olarak ifade etmiştir. Rönesans ise yeni ilmin doğuşuna hizmet ederek Sonsuz Bir'i çağrıştıran yeni bir âlem anlayışı geliştirmiştir.

Modern felsefede Descartes, sonlu töz ve sonsuz töz ayrımını yaparak düalist bir tavır sergilemiştir. Filozof, sonlu tözü kendi içinde ikiye ayırır: Ruh ve beden. Madde konusunda kısmi bir monizm/tekçilik kabul ederken, ruh konusunda kısmı monizmi reddeder. Spinoza ise tek tözü kabul eder; fakat modusların monizmini reddederek, onların çokluğunu/ahengini ortaya koyar. Filozofa göre, zihinsel dünya ile 
fizikî dünya, iki farklı bakış açısından betimlenen bir ve aynı şeyi temsil eder. ${ }^{5}$ Leibniz ise tözsel monizmi reddederken modusların monizmini kabul eder. Zira Leibniz'e göre güç/kuvvetten oluşan monadlar tek çeşittir. Filozof, zihin ve beden arasındaki ilişkiyi açıklamak için monadlar monadı Tanrı'nın önceden tesis etmiş olduğu ahenge müracaat eder.

XIX. yüzyılda ise monizm kavramının anlamı genişlemiştir ve bağlama göre bilinir hale gelmiştir. Monizmin reddi düalizme ve plüralizme yol açmıştır. Plüralizm "blok kainat" fikrine karşı çıkmış, mantıksal olarak zorunlu olma fikrinin dayanaksız olduğunu ileri sürmüştür. Örneğin Russell, evrenin, birlik, süreklilik, tutarlllık, düzenlilik veya aşk tarafından yönetilen hiçbir özelliğinin olmadığını ifade etmiştir. Bütünüyle idealist olan ve dolayısıyla bir olan gerçekliğin, ilahi olmaktan ziyade rasyonel olduğunu öne süren birciliğin tarihinde en bilinen örneği Hegel'in nesnel idealizmi veya rasyonel mutlakçılığıdır. Nitekim o, gerçekten var olanın kendisinin Geist adını verdiğini, nesnel akıl, devasa zihin olduğunu, evrenin Geist için var olduğunu öne sürmüştür. William James ise eşyanın parçalarının birbirine asılı olarak ve çözülme potansiyeline sahip olarak bir birlik oluşturduğunu, bu duruma monizm denilemeyeceğini; onun bir plüralizmi seslendirdiğini ifade etmiştir.

Modern dönemde kesin sınırlarla ayrılmış varlıklar yerine birbirinden ötekine geçebilen fakat yine de her biri ayrı kalan varlıkların çokluğu düşüncesi doğmuştur. Whitehead, zamanımızın da kabul ettiği bu düşünceyi sürekli ile süreksizin birliği şeklinde ifade etmiştir. Einstein, Heisenberg, M. Planck gibi düşünürler sonlu varlıklarda daima "göreli" ve "karşıt" terimler bulduğumuz halde, sonsuz varlıkta bu göreliliğin ve karşıtlığın kalktığını, hatta birleştiğini; mutlak karşısında görelilik durumumuzun bir bilgisizlik olduğunu ifade etmişlerdir. Nitekim günümüzün ilmi "görelilik" fikrini matematik ve fiziğin temeli haline koyarken, sonlu varlığı sonsuz varlıkla kuşatmayı ve ikincisi hakkındaki davranışımızı bilginin zıttı olarak görmeyi ummuşlardır. ${ }^{6}$

İslam düşüncesinde varlıkların evrimi, kaynaktan çıkış, açılış ve kaynağa yeniden dönüş şeklinde "devr" teorisinde ifade edilmiştir.

\footnotetext{
${ }^{5}$ İbrahim Emiroğlu, "Bircilik", Felsefe Ansiklopedisi, Editör, Ahmet Cevizci, Etik Yayınları, Cilt II, İstanbul, 2004, s. 647.

${ }^{6}$ Hilmi Ziya Ülken, Varlkk ve Oluş, Ankara Üniversitesi Basımevi, 1968, s. 102.
} 
İhvan-1 Safa risalelerinde bu tarzda bir evrim teorisi açıç̧a görülür. İslam düşüncesinde yaygın olan "zorunlu varlık" ve "mümkün varlık" ayrımı İlahi isimlerin izharına işaret eder. Bir ve Çok ilişkisini yansıtan bu görüş, birliğin bir çokluğa, çokluğun ise kendisini ayakta tutan ve varlığını sürdürmesini temin eden bir birliğe sahip olduğudur. ${ }^{7}$ Demirli, çokluktaki birliğin esasta ilahi isimlere dönen birlik olduğunu; âlem veya âlemin içindeki her bir şeyin ilahi isimlerin mazharı olduğunu, yani bu ismin o şeyin var olmasını temin ettiği gibi, aynı zamanda onun çeşitliliğini de ortaya koyduğunu beyan eder. Çünkü ilahi isimlerin varlıkla ilişkisi bir anda gerçekleşip nihayete eren bir eylem olarak tasavvur edilmez; aksine her an her durumda bu ilişki sürer. Bu süreklilik, zorunluluk hükümlerinin çokluk hükümleriyle (imkan) birlikte bulunması diye de isimlendirilir. Bu durumda zorunluluk hükümleri bir şeyin varlığını sürdürmesini temin ederek bilmek, idrak etmek, sevmek vb. olumlu fiilleri de mümkün kılar. Anlaşılacağ1 gibi bir bütün olarak âlemin birlik yönü insan-1 kâmilde gerçekleşir. ${ }^{8}$ Bunun anlamı, varlığın zuhurunun kemale erdiği mertebenin insan-1 kâmil olduğu, yani insanın kendisinde var olmasıyla şehadet mertebesinin gerçekleştiğidir. Böylelikle varlık dairesi tamamlanır, zuhur nihayete erer. ${ }^{9}$

Anlaşılacağ1 üzere yukarıda ortaya konulanlar insanoğlunun gerçekliği sezebildiğini ama onu açık ve seçik bir şekilde kavrayamadığ1$\mathrm{n}$ tasvir eder. Bizim bu dünyada ulaştığımız veya ulaşma gereksinimi duyduğumuz bir/lik/ler, duyu âlemindeki bir/lik/ler veya zihinsel bir/ lik/lerdir. Bu dünyada ancak çoğul bir/lik/lere ulaşabiliyoruz. Gerek çokluk gerekse bir/lik/ler, -başka işlevlerle birlikte- 'bizi, her daim tekil bir Bir'e inanmaya götürme işlevine sahiptirler. Bir/lik/ler tek bir Bir'e işarettir. Rasyonalistler, bir'e ircanın Tanrı'nın delili olup a priori olduğunu kabul ederler. Ancak âlemde çokluk paranteze alınsaydı, birlik fikrinin farkında olabilir miydik? Bu farkındalık olmadan, birliğin, a priori bir fikir olduğu temayülü gösterilebilir miydi? Bu noktadan hareketle şunu söyleyebiliriz: Hakkında konuşabildiğimiz bir, ancak bir/lik/lerdir. Bu bir/lik/ler çoklarla bilinirler ve kendileri de birçoğu toplayarak çeşitli birler kümesi oluştururlar. Tüm bunlar bu âlemde,

\footnotetext{
${ }^{7}$ Ekrem Demirli, Sadreddin Konevi'de Bilgi ve Varlik, İz Yayıncllı, 2011, s. 228.

${ }^{8}$ Ekrem Demirli, Sadreddin Konevi'de Bilgi ve Varlk, s. 229.

${ }^{9}$ Ekrem Demirli, Sadreddin Konevi'de Bilgi ve Varlik, s. 255.
} 
üzerinde konuşulamayan, ama konuşulduğu an bir/lik/lere indirgenme riski taşıyan, Bir olana işaret ederler.

Varolanların varlıkta görülmesi ya da Bir'de toplanması esasen varlığın ontolojik bir uzlaşı gösterdiğini resmeder. Tüm evren canlı bir varlıktır; içindeki tüm varlıklar, tüm olup bitenler ve tüm parçalarıyla bütün bir varlıktır. Varlıkta gizli halde bulunan ya da açığa çıkan uzlaşı, kültürümüzün ifadesiyle birlik/tevhit kendisini insan hayatında gösterir. İnsanın varolanlarda düzeni görmesi ya da karışıklıktan kaçması varoluşun doğası gereğidir. Nitekim görünüşteki düzenler insanı doyurmamış, kimi zaman bulabildiği düzenler bazı açıklamalara imkân verse de insan bunlardan daha köklü düzenlere ulaşmaya çalışmıştır. Sonsuz tekil olayların karışıklığı ile parçalı açıklamaların arasında sıkışıp kalan insan olayların kaosu içinden sızan ışık ümidinden vazgeçmemiştir. Zira insan kendisini varlık bütünlügünden ayrı görmemiş, her daim ona eklemlenmeye çalışmıştır. İnsan hayatında önce açıklamaların çatışması, ardından doktrinlerin çatışması, daha sonra birbirini reddeden görüşler ile inhisarcı yaklaşımlar arasında doğruyu bulmak, her devirde yenileşen bir uzlaşma halinden kaynaklanmıştır. Her yeni aşama eskisine bir şey katmakta ve onu geliştirmektedir. Varoluşun derununda devam eden bu diyalektik, esasen hayatın çatışma ve uzlaşma zemininde sürdürülebilirliğini temsil etmektedir. $\mathrm{Bu}$ sürdürülebilirlik, onun değişim ve süreklilik gergefinde nasıl bir yol izlediğini keşfetmekle gerçekleşir. Bu mesele varoluşun her daim araştırılmasını bize telkin eder.

\section{Uzlaşmanın Aksiyolojisi}

Uzlaşmanın nihayetinde ahlaki bir hadiseye işaret ettiği açıktır. Bu hadise, irade sahibi bir varlığın yine irade sahibi bir varlıkla değerler alanına katılımını ya da oradaki buluşmasını temsil eder. İnsanoğlunun manevi âlemini teşkil eden bu değerler alanı birlik ve yetkinliği kendisinde toplar. Başka bir ifadeyle insanoğlu bu manevi âleme yaklaştıkça birlik ve yetkinlik kazanır; ondan uzaklaştıkça birlik ve yetkinliğini kaybeder. Eğer ahlaki hayatın yaşanmış varlık olarak değeri ifade ettiğini akılda tutarsak, en üstün değerin birlik ya da kültürümüzün ifadesiyle tevhit olduğunu söyleyebiliriz. Değerler alanındaki birlik, "âlemde ya da kâinattaki birliği" ve oradan "insanlıktaki birliği" seslendirir. İnsanlıktaki birliğin sağlanması ise, esasen iradelerin böyle 
bir birliği murat etmesine ve bu yolda gayret göstermesine bağlıdır. Bu noktada değerlerin var olmasının yegâne sebebinin insanda iradenin mevcut oluşu olduğunu hatırda tutarsak, değerler dünyası ile iradeler dünyasının mantıken birbirlerinden ayrilmaz yapıda olduğunu fark ederiz. Zira değerler alanı her daim başka öznelerin/iradelerin yönelimlerinin bulunduğu bir alana işaret eder. Bu alan, özneler arasındaki ilişkileri kuşatan aşkın bir sahaya işaret ettiği için değerler, yalnızca iradi mücadele içinde ötekinin/diğerinin tanınmasıyla başlamaz; ama aynı zamanda ahlaki bir özne olarak konumuyla uyumlu bir şekilde onun düşünceleri, planları ve amaçları olduğu gerçeğini tanıma veya tasdik ve buna saygı duymayla başlar. Ötekinin tanınması, ahlakın ilk ilkesi olarak esasen 'dünyadaki herhangi bir değerin başka herhangi bir değer kadar gerçek olduğunu tanıma’ anlamına gelir. Başka değerlere saygı duyma; değerlerini bırakmayı değil, ama değerlerini kendi iradelerinden çok, toplumsal kurumlara bağlı olan bir dönüşüm yoluyla uyumlulaştırmaya çabalama anlamına gelmelidir. Bu noktada tarafsızlık bir başkasının değerlerine samimiyetsizlik veya ilgisizlik hâli değil; bilakis saygı yoluyla bağlantı kurmaktır. Çünkü "değerler dünyasının hakikati" bu dünyada bir değerlendirmenin yer aldığı durumda, bunun senin mi yoksa benim mi olduğunun temel teşkil etmediği anlayışıyla başlar. Değerler dünyasını, ilk önce, kim yaparsa yapsın bütün değerleri 'tahammülkâr' bir şekilde, tüm insanlar tarafından kendi zaman ve mekânları içinde bir olgu ve sade bir değer olgusu olarak ele alınması gereken "kendinde şeyler" olarak görmeye çalışmak gerekir. İkinci olarak, hayatı uyumlulaştırmaya çalışan değerleri ve fiilleri daha önemli kabul etmek gelir. Bu noktada makul olmak, değerleri seninkilerle çelişen bir başka insanla kavga etmek yerine, savlar kullanmayı, ahlaki bakımdan onları ikna etmeyi ya da onlarla uzlaşmayı ifade eder.

Ahlakın insanlar arası ilişkilerde aşkın bir alan, bir değer sahası olarak görülmesi; tüm insani eylemlerin, düşüncelerin, ifadelerin ahlaki varlık sahası tarafından kuşatılmış olduğu ve orada cereyan ettiği düşüncesinden kaynaklanır. Gerçekten değerler alanı, insanın başka insanlar ve nesneler ile bağlantısında ortaya çıkan, bu yüzden de kendisini gerçekleştirmeye çalıştığımız ilkelere; yapıp etmelerimizi yönlendiren kurallara; hayatımıza yön veren pusulalara işaret eder. Onlar kendisine muhtaç olduğumuz, kendisini aradığımız, bizi tamamlayan unsurlar olarak hissedilirler. Bu hissediş en ilkelinden en 
yüksek derecesine kadar bütün değerleri içine alabilir. Bu noktada bütün değerleri tespit edebileceğimiz iki alan vardır: Bunlardan ilki tecrübî alan, yani tasavvur ve akıl yürütmelerle elde edebileceğimiz bilgi alanı; ikincisi ise, yüce ve manevi değerleri irade hayatımız ile tespit edebildiğimiz inanç alanıdır. Bu noktadan hareketle değerler alanının duyular âleminden duyulur-olmayan âleme; gerçekten ideale yönelen bir tavır, bir eylem içinde gelişip ilerlediğini ifade edebiliriz. Başka bir ifadeyle değerler alanı ahlaki bir saha olmadan önce bir varlık sahasıdır. ${ }^{10} \mathrm{Bu}$ varlık sahası, insanın manevi bir varlık haline geldiği alanı temsil eder. Bu alan; a) birlikte duymayı, b) değerlendirmeler yapmayı ve nihayetinde c)kişilik oluşturmayı temin eder. H. Ziya Ülken, birlikte duyma ve anla/ş/manın (mitleid) kuşatıcı, manevi bir varlık sahası olmadan mümkün olmadığını; bu sahada sahiplenmenin ayırıcı ve parçalayıcı olduğunu, bu alana ancak iştirak ile katılabileceğimizi, zira ahlaki varlık olarak bizi birbirimize bağlayan yanın insanlığımız olduğunu ileri sürer. ${ }^{11}$ Ona göre insanlar arası münasebeti sağlayan bu alan ancak kuşatıcı manevi ve aşkın bir varlığı kabul etmek ve ona inanmakla mümkün olabilir. ${ }^{12}$

Açıktır ki ahlakın, manevi varlığın özel sahası olarak nitelenmesi hatta bir yaşama biçimi olarak insaniyetin ancak onunla ayakta durmasının mümkün olduğunun iddia edilmesi; onun hem aşkın bir alanla hem de insanlar arası bir alanla irtibatlandırılmasına; ahlaki eylemin her iki alandan gelecek hususiyetlerle tesirli kılınmasına yöneliktir. Aşkın alan ya da erdemler/değerler sahası genel olarak failin (sübjektif olarak/arzu vasıtasıyla) karar alma ve (objektif olarak/mani ederek) düzenle/n/me temayülünü sağlar. Bu çerçevede değerlerin etkiledikleri için zaman üstü, insanda gerçekleştikleri için de zamansal olduğu söylenebilir. Başka bir ifadeyle değerler hem sabit hem de değişken alana işaret eder. Nitekim bu duruma dikkat çeken Ülken, eğer değer yalnızca kararlılıktan ibaret olmuş olsaydı, o zaman onun Parmanides'in varlık'ı gibi olacağını; bu takdirde orada her türlü ölçü ve değerlendirmenin lüzumsuz olacağını ve mutlak bütünlügün hüküm süreceğini; hatta her hatanın düzeltilebileceğini, her şeye esef

\footnotetext{
${ }^{10}$ H. Ziya Ülken, Felsefeye Giriş II, (Ankara Üniversitesi İlahiyat Fakültesi Yayınları, 1958) s. 193194

${ }^{11}$ Ülken, Felsefeye Giriş II, s. 192-195.

12 Ülken, Felsefeye Giriş II, s. 196.
} 
edilmeyeceğini ve değerlendirmeye de lüzum kalmayacağını beyan eder. Diğer taraftan değer yalnızca karar hususundan ibaret olsayd, yani sırf kuvvet ve arzu olsaydı, o vakit değer alanının Herakleitos'un bize anlatmış olduğu âleme benzeyeceğini ifade eder. Bu durumda her şey elimizden kaçacak, devam etme, inanç ve ümidin imkânı kalmayacaktır. Ülken, gerek süjelere gerekse eşyaya yönelmiş olsun bütün değerlendirmelerimizin, bu zit ve tamamlayıc1 vasıfları haiz olan yerde gerçekleştiğini ileri sürer. ${ }^{13}$ Nitekim Burhanettin Tatar bu hususu ahlaki derinlik meselesi kılarak şöyle açıklar: Ahlak tecrübesi her şeyin ötesinde "özne" denilen şeyin eleştirisi olarak "dışardan gelen sese kulak vermekle" oluşur; ahlaki niyetlerimizin gerisinde "ahlaki dinleme" yeteneğimiz yer alır; ahlaki ilkelerin normatifliği doğrudan ahlak ilkelerinin kendisinden değil; dişardan gelen sesin gücünden ve aciliyetinden kaynaklanır. Tatar'a göre ahlaki deneyim, dışardan gelen sese kulak vermek, onu alımlamak ve onun çağrısına uygun düşecek şekilde davranmakla mümkün olur. Daha açık bir ifadeyle Tatar, ahlak hadisesinin öznenin kendi dışına taşarak yeniden kendine dönüşüyle gerçekleşeceğini iddia eder. ${ }^{14} \mathrm{Bu}$ husus ahlakın aktüel davranışı aşan bir ideal önerdiği ve deneyimin tüm yaptırımlarını aşan bir zorunluluğu içerdiği olgusuna işaret eder.

Değerler alanını bir kararlılık alanı olarak görmek, değeri kararlılık açısından ideal, kararsızlık ve değişme olmak bakımından da reel olarak kabul etmek anlamına gelir. Nitekim bu kabulün içerimi, değerler alanının bir zorunluluk alanı olduğu kabulünü beraberinde taşır. Ancak bu zorunluluk bizi, Kant'in anladığı gibi değeri sadece kararlılık kabul ettiğimiz çerçevesinde mutlak zorunluluğa götürmez. Ülken, değerler alanının tam bir zorunluluk ile tam bir hürlügün arasında bulunan ve asıl gerçekliğin vasıflarına uygun bulunan muhtemel bir alana işaret ettiğini beyan eder.15 Bu muhtemel alanda her türlü değerlendirme, en az muhtemelden en çok muhtemele doğru ilerler ve daima bu iki derecenin arasında bir çift-değer olarak kalır. Şöyle ki bu çift değerlerden birisi pozitif diğeri negatiftir; her iki değer gerçeğe ve arzu faktörüne dayandığı ve birbiri üzerinde aktif olduğu için, birinin

\footnotetext{
${ }^{13}$ Ülken, Ahlak, Ülken Yayınları, İstanbul, 2001, s. 154.

${ }^{14}$ Burhanettin Tatar, "Ahlakın Kaynağı", İslam’a Giriş Ana Konularıyla Yeni Yaklaşımlar, ed. Bünyamin Erul, (DİB Yayınları, İstanbul, 2008) s. 207-208.

${ }^{15}$ Ülken, Ahlak, s. 155.
} 
düzenle meydana getirdiği netice diğerinin düzenle meydana getirdiğinin zıddı olur. Sözgelimi doğru bir söz değer olduğu gibi, yalan söz de bir değer olur. Fakat yalan menfi bir değerdir. Başka bir açıdan doğru söylemenin bir değer olabilmesi için doğru söyleyenin yalan söyleyebilecek halde bulunması, fakat bu duruma rağmen doğru söylemesi gerekir. Bu çift değerliliğin ahlaki alana ait bir özellik olduğunu beyan eden Ülken, Antik Yunan düşüncesinde Platon ve Aristoteles'in etkisiyle değer sorununun -elbette tarihsel olayların etkisiyle- akıl edilirlik zemininde ele alındığını ve sonuçta değer probleminin hakikat problemi içinde eridiğini iddia eder. ${ }^{16}$ Oysa ona göre değerleri asıl kavrayan ve değerlendirmeyi temin eden teessüri-fiili hayatımız çift kutupluluk vasfına sahiptir ve çift değerliliği her daim sergiler. ${ }^{17}$ Ahlaki deneyimin alanında gerçek ve ideal olmak üzere iki düzen olduğunu ileri süren Ülken, ilk, yani gerçek düzenin insanda arzu ve kuvvet faktörünün engellenmesiyle oluştuğunu; ikinci düzenin, yani ideal düzenin ise değer deneyiminden sonra kişiliğin doğuşuyla beraber gelişen değer yaratması safhası olduğunu beyan eder. ${ }^{18}$ Ahlaka dair böyle bir kavrayış, gerçeğin verdiği kararlılık ve devam duygusunun ideal düzen için dayanak olduğu anlamını yansıtır.

Ahlakı, ideal düzen ya da nihai gayeye varmanın bir yolu/sanatı olarak değerlendiren bu anlayışa göre insan ister bireysel, isterse kolektif olarak, iyilik ve tekâmülünü gerçekleştirmelidir. Bu süreçte ahlaki erdemler mutluluğu elde etmenin aracı olarak işlev görürler. ${ }^{19}$ Erdemlerin araç olarak görülmesi, onların esasen mutluluğun üreticisi olmadiğını temin içindir. Zira reziletler bu araçların inkârı olduğu için gerçek mutluluğun tezahürü imkânsızlaşır. Araçlar ile amaçların ayrılmadığı, hatta çoğu zaman karıştığı bu anlayışta erdemlerin insanı mutlu kılması umulur; çünkü iyi, mutluluk ya da mutsuzluk olarak tezahür eder. Bu hususun kabulü mutluluğun kazanılmasının, araçları nasıl elde ettiğimiz ve onları nasıl kullandığımız hususuna bağlı olduğunu gösterir. Bu çerçeve göz önüne alındığında ahlak, insanın mutluluk arayışında doğru tavrı sergilemesi olarak anlaşılır. Bu anlayış zorunlu olarak şu hususları gerektirir; 1)Araçlar ve gayeler birbirine bağlıdır,

$\overline{16}$ Ülken, Ahlak, s. 158.

${ }^{17}$ Ülken, Ahlak, s. 156-162.

${ }_{18}$ Ülken, Ahlak, s. 164.

${ }^{19} \mathrm{Bkz}$. Aristoteles, Nikamakos'a Etik, çev. Saffet Babür, (Bilgesu Yayıncılık, İstanbul, 2009) s. 42;43;52;133. 
dolayısıyla iyi bir eylemin mutluluk arzusuyla beraber mutluluğun kendisini de birbirine bağladığı kabul edilir. 2)Ahlakın olmadığı yerde araçlar ve gayelerin bağlı olmadığı, hatta mâniaların bu kopukluğu ürettiği söylenebilir. Bu şekilde ele alındığında ahlakın ya vasıtalar ya da kendisiyle yaptırımı sağladığı görülebilir. Zira erdemli davranış ile mutluluk arasında bir bağlantı olduğu kabul edilmiştir. Hatta bu noktada şahsi bir erdemin sadece sahibine değil insanlığa faydalı olduğu ya da olacağı da çoğu kimse tarafından kabul edilmiştir. Bu durumun tersi, ahlaki eylem ile sonuçları arasında mânialar olduğu; bu engellerin hem içimizde hem de dişımızdaki doğada olduğunun kabulüdür. Aynı şekilde fertlerin oluşturduğu toplum için de benzer mâniaların olduğu da varsayılır. Bu çerçeve kabul edildiğinde ahlaki yaptırımların olmadığını söyleyenler ya da onları inkâr edenler, ahlak ile sonuç arasında hiçbir kozal bağlantının olmayacağını söylemiş olurlar. Oysa en azından deneyimlerimizde ahlaki yaptırımı çoğu kez neşe olarak, yokluğunu ise -kaybımız vasıtasıyla- elem olarak tecrübe ettiğimiz söylenebilir.

Ahlak esasen bireysel olsa da ve bireysel sonuçlar üretse de, sonuçlarının toplumu ilgilendirdiği de aşikârdır. Ahlakın mahiyetinin tam bu noktada tüm insanlık ailesini içermesinde yattığı söylenebilir. Bununla beraber bazı insanların genelin iyiliğine kurban olmaması gerektiği de kabul edilmelidir. Mutluluk arzusu her bireyde tek tek ortaya çıksa da uzlaşma vasıtasıyla tüm insanlığı kapsamalıdır. Zira ferdin nihai refahı, son tahlilde grubun amacına ve eylemlerine bağlı olacaktır. Ahlakı, bireyin mutluluğu elde etmesi ya da erdemi gerçekleştirmesi olarak gören bu anlayış, ahlaki failin her daim kötülüklerin tehdidi altında olduğunu da kabul etmiş olur. Âlemde toplam kötülük çoğu zaman azaltılamaz mahiyette kaldığı için, insan ırkının şimdi ve gelecekteki mutluluğu bu kötülügün miktarına ve bu miktarı azaltmadaki gayretlerimize bağlı olacaktır. Bu hususun izale edilmesi, toplumdaki bireylerin çabalarıyla, yeryüzünde iyi veya kötünün etkilerini nasıl deneyimledikleriyle ve nihayetinde uzlaşmayı nasıl ortaya koyacaklarıyla yön bulacaktır.

Günümüzde uzlaşma, herkesin kendi kalarak ortak iyide uzlaşması olarak anlaşılmaktadır. Gerçekten uzlaşma, kişinin kendinden vazgeçmesi, ödün vermesi, değişmesi ve dönüşmesi değil , kendisiyle öteki arasında gerçek bir barış ve güvenlik ortamı sağlama yönündeki 
çaba olarak görülmelidir. Bu çerçevede uzlaşma, ayrışmanın karşıtıdır ve her türden ayrışma sözlüğümüzdeki karşılığıyla 'gayrılık’a tekabül eder. Bu yüzden uzlaşma ya da birlik duyarlılığını engelleyen her türlü gayrılığa karşı çıkma ve direnme benliğin, insanlığın ve kâinatın kurtuluşuna yardım etmedir. Aynı şekilde adil, katılımcı ve eşitlikçi bir dünya düzeninin anlamı, herkesin aynı şekilde düşünüp yaşamasında değil, farklı görüşlerin bir arada var olma kararlılığı gösterebilmesinde kendisini göstermektedir. İnsanlığımızın birlikte yaşarken tezahür ettiğini düşündüğümüzde ne benim dediğimin ne senin dediğinin değil; bizim dediğimizin esas alınması lazım geldiğini; uzlaşmaya ya rıza yoluyla ya da zorunlu biraradalıklarla varmamız gerektiğini varsayabiliriz. Bununla beraber yukarıda ortaya konan görüşler uzlaşmayı tarif etse de, onun görünen ile tanımladığımızdan, anlayabildiğimizden, yaşayabildiğimizden daha fazlasına ve daha büyüğüne gönderme yapacağı unutulmamalıdır. Aynı şekilde uzlaşmanın, bireysel ya da belli bir zaman ve mekân içerisindeki deneyimlerimizle bilinse de, asla onlara indirgenemeyeceği; tezahürlerini anlasak bile asla mahiyetine nüfuz edemeyeceğimiz, her daim oluşan ve oluşmakta olan bir hususa gönderme yaptığı hatırlanmalıdır. 


\section{KAYNAKÇA}

Aristoteles, Nikamakos'a Etik, çev. Saffet Babür, Bilgesu Yayıncılık, İstanbul, 2009.

TATAR, Burhanettin. "Ahlakın Kaynağı", İslam’a Giriş Ana Konularıyla Yeni Yaklaşımlar, ed. Bünyamin Erul, DİB Yayınları, İstanbul, 2008.

TÜRER, Celal. “Pragmatizm'in Doğruluk Evi”, Bilimname, XVII, Kayseri, 2009.

DEMİRLİ, Ekrem. Sadreddin Konevi'de Bilgi ve Varlık, İz Yayıncllı, İstanbul, 2011.

ÜLKEN, H. Ziya. Ahlak, Ülken Yayınları, İstanbul, 2001.

ÜLKEN, H. Ziya. Felsefeye Giriş II, Ankara Üniversitesi İlahiyat Fakültesi Yayınları, Ankara, 1958.

ÜLKEN, H. Ziya, Varlık ve Oluş, Ankara Üniversitesi Basımevi, Ankara, 1968.

EMİROĞLU, İbrahim. "Bircilik", Felsefe Ansiklopedisi, Editör, Ahmet Cevizci, Etik Yayınları, Cilt II, İstanbul, 2004.

HEİDEGGER, M. Varlık ve Zaman, çev. Kaan. H. Öktem, İstanbul, 2008.

JAMES, William. Pragmatism, New York, 1907.

KUTLUSOY, Zekiye. "Doğruluk Kuramları" Felsefe Ansiklopedisi, ed. Ahmet Cevizci, Ankara, 2006, C. 4. 